\title{
ZAKAT PROFESI PERSPEKTIF NELAYAN DI DESA DHARMA TANJUNG KECAMATAN CAMPLONG KABUPATEN SAMPANG
}

\author{
Ananda \\ (Fakultas Syariah, IAIN Madura, Jl. Raya Panglegur km. 4 Pamekasan, \\ email:hafizh.forever@gmail.com) \\ Azhar Amrullah Hafizh \\ (Fakultas Syariah, IAIN Madura, Jl. Raya Panglegur km. 4 Pamekasan, \\ email: hafizh.forever@gmail.com) \\ Rusdiana Navlia \\ (Fakultas Tarbiyah IAIN Madura, Jl. Raya Panglegur km. 4 Pamekasan, \\ email: rusdiananavlia005@gmail.com)

\begin{abstract}
Abstrak:
Zakat profesi adalah sebuah terma zakat baru yang masih sangat kontroversial. Salah satu sebabnya adalah problem zakat profesi bagi masyarakat berpenghasilan rendah seperti nelayan yang belum memiliki persepsi yang benar tentang zakat profesi terutama di Desa Dharma Tanjung Kecamatan Camplong, Kabupaten Sampang, sehingga dalam pelaksanaannya, ada kesalahan dalam penyaluran zakat tersebut. Dari fenomena tersebut timbul beberapa pertanyaan yaitu: Pertama, Bagaimana pandangan masyarakat nelayan tentang zakat profesi di Desa Dharma Tanjung Kecamatan Camplong, Kabupaten Sampang; Kedua, Bagaimana implikasi dari pandangan tersebut. Penelitian ini menggunakan pendekatan kualitatif dengan jenis penelitian fenomenologi. Penelitian ini menunjukkan bahwa Masyarakat nelayan di Desa Dharma Tanjung Kecamatan Camplong Kabupaten Sampang dalam mengeluarkan zakat mengikuti apa yang ada dipikirannya sendiri dan tidak mengikuti ajaran agama Islam. Sedangkan Implikasi dari pandangan masyarakat tersebut adalah adanya kesalahan dalam penentuan nisab zakat dan adanya salah sasaran dari obyek sasaran zakat. (Professional Zakat is a new term of charity which is still very controversial. One reason is the problem of professional zakat for low-income people such as fishermen who do not have the correct perception of professional zakat, especially in the Village of Dharma Tanjung, Camplong Subdistrict, Sampang Regency,
\end{abstract}


Ananda

Azhar Amrullah Hafizh

Rusdiana Navlia

so that in the implementation, there was an error in the distribution of zakat. From these phenomena arose several questions, namely: First, What is the view of the fishing community about professional zakat in the Village of Dharma Tanjung, Camplong District, Sampang Regency; Second, what are the implications of this view. This study uses a qualitative approach to the type of phenomenological research. This research shows that fishing communities in the Village of Dharma Tanjung, Camplong Subdistrict, Sampang Regency in issuing zakat follow what is on their own mind and not following the teachings of Islam. So that the implication of the community's view is that there is an error in determining the Nisab Zakat and the misdirection of the zakat target object).

Kata Kunci:

Zakat Profesi, Nelayan, Tanjung Sampang.

\section{Pendahuluan}

Zakat, infaq dan shadaqah merupakan salah satu potensi Umat Islam yang dapat disumbangkan dalam pembangunan Nasional guna meningkatkan taraf hidup dan kesejahteraan masyarakat serta sebagai salah satu alternatif pemberantasan kemiskinan.

Zakat dalam agama Islam adalah kewajiban individual atau fardlu 'ain bagi setiap umat (dengan syarat tertentu). Kewajiban ini sama dengan kewajiban-kewajiban lainnya seperti shalat, puasa dan ibadah haji. Semua ini merupakan kewajiban yang harus di tunaikan oleh umat Islam.

Sebagaimana firman Allah swt.:

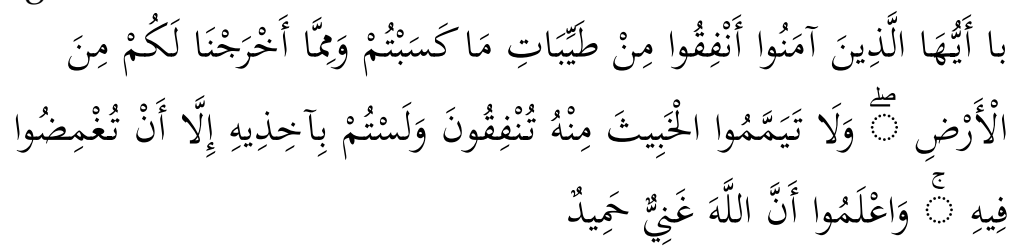

Hai orang-orang yang beriman, nafkahkanlah (di jalan Allah) sebagian dari hasil usahamu yang baik-baik dan sebagian dari apa yang Kami keluarkan dari bumi untuk kamu. dan janganlah kamu memilih yang buruk-buruk lalu kamu menafkahkan daripadanya, Padahal kamu sendiri tidak mau mengambilnya melainkan dengan 
memincingkan mata terhadapnya. dan ketahuilah, bahwa Allah Maha Kaya lagi Maha Terpuji. (Qs : Al-Baqarah Ayat : 267)1

Hasil profesi (pegawai negeri/swasta, konsultan, dokter, notaris dll) merupakan sumber pendapatan (kasab) yang tidak banyak dikenal di masa salaf (generasi terdahulu), oleh karenanya bentuk kasab ini tidak banyak dibahas, khususnya yang berkaitan dengan "zakat". Lain halnya dengan bentuk kasab yang lebih populer saat itu, seperti pertanian, peternakan dan perniagaan, mendapatkan porsi pembahasan yang sangat memadai dan detail. Meskipun demikian bukan berarti harta yang di dapatkan dari hasil profesi tersebut bebas dari zakat, sebab zakat pada hakikatnya adalah pungutan harta yang di ambil dari orang-orang kaya untuk dibagikan kepada orang-orang miskin di antara mereka (sesuai dengan ketentuan syara').

Dengan demikian apabila seseorang dengan hasil profesinya ia menjadi kaya, maka wajib atas kekayaan itu zakat, akan tetapi jika hasilnya tidak mencukupi kebutuhan hidup (dan keluarganya), maka akan menjadi mustahiq (penerima zakat). Sedang jika hasilnya hanya sekedar untuk menutupi kebutuhan hidupnya, atau lebih sedikit maka baginya tidak wajib zakat. Kebutuhan hidup yang dimaksud adalah kebutuhan pokok, yakni papan, sandang, pangan dan biaya yang di perlukan untuk menjalankan profesinya.

Zakat profesi memang tidak dikenal dalam khasanah keilmuan Islam, sedangkan hasil profesi yang berupa harta dapat di kategorikan ke dalam zakat harta (simpanan/kekayaan). Dengan demikian hasil profesi seseorang apabila telah memenuhi kebutuhan maka wajib baginya untuk menunaikan zakat. ${ }^{2}$

Yusuf al-Qardhawi menyatakan bahwa di antara hal yang sangat penting untuk mendapatkan perhatian kaum muslimin saat ini adalah penghasilan atau pendapatan yang di usahakan melalui keahlian yang dilakukan secara sendiri (seperti: profesi dokter, arsitek, ahli hukum, penjahit, pelukis, dai atau mubaligh) maupun secara bersama-sama (seperti: pegawai pada satu instansi pemerintah, BUMN ataupun BUMD, karyawan pada BUMS yang mendapat gaji

\footnotetext{
1 Departemen Agama Republik Indonesia, Al-Qur'an dan Terjemahan (Jakarta:Yayasan Penyelengara Penterjemahan Al-Qur'an, 1971), 45.

2 Zainal Abidin, Figh Kontemporer (Pamekasan: STAIN Pamekasan Press, 2010),. 63-64.
} 
Ananda

Azhar Amrullah Hafizh

Rusdiana Navlia

dalam waktu relatif tepat). Penghasilan-penghasilan tersebut dalam istilah figh di sebut dengan al-Mal al-Mustafad.

Secara umum zakat profesi menurut hasil putusan Tarjih Muhammadiyah adalah zakat yang dikeluarkan dari hasil usaha yang halal yang dapat mendatangkan hasil (uang), relatif banyak dengan cara yang halal dan mudah, baik melalui keahlian tertentu maupun tidak. Sedangkan dalam pemahaman Zamzami Ahmad, zakat profesi adalah penghasilan yang didapat dan diterima dengan jalan yang halal dalam bentuk upah, honor ataupun gaji.

Secara lebih tegas lagi, hasil seminar Damaskus tahun 1952 menetapkan bahwa hasil usaha profesi adalah sebagai sumber zakat, karena terdapat alasan (illat) yang menurut ulama fiqh sah dan ada nisab yang menjadi landasan wajibnya zakat. Di samping itu, berbagai sektor profesi sekarang ini telah memberikan nilai penghasilan yang pada satu sisi justru lebih besar dari sektor usaha dan kekayaan yang disebutkan dalam nash-sebagai kewajiban zakat.

Terlepas dari kontroversi persoalan wajib dan tidaknya, masuk atau tidaknya profesi dalam kategori zakat, logika nurani perlu menjadi pertimbangan pada era ini. Dawan Raharjo menilai, bahwa zakat adalah merupakan konsekuensi teologis, yaitu cara bagaimana manusia berkepercayaan kepada Allah, dan zakat yang ditunaikan dengan mengeluarkan sejumlah kekayaan tidak berarti zakat yang sebenarnya, jika tidak didasarkan pada kepercayaan kepada Allah.

Nilai filosofis perintah zakat adalah untuk menciptakan rasa sosial dan keadilan. Adalah ironis, jika petani yang manggarap sawah/ladang dituntut mengeluarkan zakat setiap kali panen bila mencapai nisab, sementara mereka yang bergelut di sektor usaha dan profesi (dokter, konsultan, kontraktor, ahli komputer, bankir, teknisi, advokat, designer, apoteker, psikolog, peneliti, pengarang dan sebagainya) yang berpenghasilan lebih besar dan lebih mudah tidak dituntut untuk berzakat. ${ }^{3}$

Istilah ini sebenarnya telah banyak dikenal, tetapi memang belum memasyarakat. Zakat profesi itu adalah zakat atas penghasilan sebagai imbalan dari pekerjaan atau jasa yang dilakukannya. Misalnya, seorang menerima gaji, upah, bonus, hadiah, intensif atau

\footnotetext{
${ }^{3}$ Amiruddin Inoed, Anatomi Fiqh Zakat (Palembang: Pustaka Pelajar, 2005),. 51.
} 
sebagainya: seorang dokter, seorang pengacara, atau seorang akuntan penerima honor, seorang perantara (pialang) menerima komisi dll.

Jadi zakat profesi adalah zakat dari setiap penghasilan yang diterima oleh seseorang yang merupakan imbalan atas kerja atau jasanya. Zakat profesi penting untuk dibahas, karena banyak orang yang bingung tentang hakikat dari zakat profesi itu sendiri, dan sejauh mana kewajiban yang harus ditunaikan dari penghasilan yang diterimanya itu. Sejauh ini memang belum ada jawaban yang tegas terhadap kedudukan penghasilan seperti tersebut di atas. Pertanyaan tersebut bukan hanya datang dari mereka yang mempunyai penghasilan besar saja, akan tetapi juga dari mereka yang hidup dari gaji yang tidak seberapa, yang hanya cukup untuk biaya hidup sehari-hari.

Ada orang yang ingin mengeluarkan zakat atas penghasilan yang diterimanya itu, baik besar maupun kecil. Akan tetapi mereka tidak mengerti berapa nisabnya, dan bagaimana cara menghitungnya, berapa kadar zakatnya, kapan harus dibayarkan, serta pada siapa harus diserahkan ${ }^{4}$.

Fenomena yang terjadi di masyarakat pesisir di Desa Dharma Tanjung, Camplong, Sampang yang sebagian besar masyarakatnya berprofesi sebagai Nelayan, bahwa pendapatan yang mereka peroleh dari hasil melaut berbeda-beda, tergantung hasil tangkapan dari laut. Penghasilan yang diperoleh digunakan hanya untuk kebutuhan mereka sehari-hari, bahkan ada sebagian yang tidak dapat mencukupi kebutuhannya.

Selain itu ada fenomena menarik yang terjadi, bahwa ada sebagian orang yang dianggap mampu untuk mengeluarkan zakat profesi namun tidak mengeluarkannya dengan alasan bahwa mereka sudah mengeluarkan zakat fitrah setiap tahunnya. Dari sini timbul beberapa pertanyaan yaitu: Bagaimana pandangan masyarakat nelayan tentang zakat profesi di Desa Dharma Tanjung Kecamatan Camplong Kabupaten Sampang? Dan bagaimana implikasi dari pandangan masyarakat tersebut. Penelitian ini menggunakan teori hukum fiqh tentang kewajiban zakat, dimana fenomena yang terjadi dikomparasikan dengan hukum di dalam fiqh zakat untuk mencari relevansi antara fenomena yang terjadi dengan hukum yang selama ini diyakini kebenarannya.

${ }^{4}$ Zakiyah Daradjat, zakat pembersih harta dan jiwa (Bandung: PT Remaja, 1991),. 52-53. 
Ananda

Azhar Amrullah Hafizh

Rusdiana Navlia

\section{Metode Penelitian}

Penelitian adalah penelitian kualitatif. Secara historis implementasi penelitian kualitatif bermula dari pengamatan. Menurut Bogdan dan Taylor, penelitian kualitatif adalah reaksi dari tradisi yang terkait dengan positifme dan postposivisme yang berupaya melakukan kajian budaya dan sifatnya interpretatif. Penelitian kualitatif bekerja dalam setting yang natural(alami), yang berupaya untuk memahami, memberi tafsiran pada fenomena yang dilihat dari arti yang diberikan orang-orang kepadanya. ${ }^{5}$

Sejalan dengan definisi tersebut, Krik dan Miller mendefinisikan bahwa penelitian kualitatif adalah tradisi tertentu dalam ilmu pengetahuan sosil yang secara fundamental bergantung dari pengamatan pada manusia baik dalam kawasannya baik dalam peristilahannya. Penelitian kualitatif dari sisi definisi lainnya dikemukakan bahwa hal itu merupakan penelitian yang memanfaatkan wawancara terbuka untuk menelaah dan memahami sikap, pandangan, perasaan, dan perilaku individu atau sekelompok orang. 6

Adapun lokasi penelitian ini bertempat di Desa Dharma Tanjung Kecamatan Camplong Kabupaten Sampang. Alasan peneliti memilih lokasi tersebut didasari atas ketertarikan peneliti terhadap pandangan masyarakat tentang zakat profesi yang biasanya dikeluarkan pada saat menjelang hari raya di Desa Dharma Tanjung Kecamatan Camplong Kabupaten Sampang, juga didasari oleh pertimbangan keterbatasan geografis dan praktis seperti waktu, biaya, tenaga dalam melakukan penelitian.

Sumber data utama dalam penelitian adalah kata-kata dan tindakan, selebihnya adalah data tambahan seperti dokumen dan lain-lain. ${ }^{7}$ Data primer dalam penelitian ini adalah data yang diperoleh langsung dari sumber pertama penelitian lapangan baik dari individu atau perorangan, seperti hasil wawancara yang dilakukan oleh peneliti. Untuk memperoleh data primer ini, penulis secara langsung mengadakan wawancara dengan masyarakat yang

${ }^{5}$ Andi Prastowo, Metode Penelitian Kualitatif ( Jogjakarta: Ar-Ruzz Media, 2012),. 23.

6 Lexy J. Moleong, Metode Penelitian Kualitatif (Bandung: PT Remaja Rosdakarya, 2014),. 4-5.

7 Ibid, 157. 
terlibat dalam problematika zakat profesi yaitu para nelayan yang memiliki kekayaan lebih seperti pemilik kapal, pemilik perahu sampan yang memiliki penghasilan mencapai nisab.

Selain data primer di atas, peneliti juga memakai data kualitatif yang bersifat deskriptif, yaitu sekedar untuk menggambarkan sejumlah variabel yang berkenaan dengan masalah dari unit yang diteliti, tanpa mempersoalkan hubungan antar variabel yang dimaksudkan untuk ekplorasi dan klarifikasi mengenai suatu fenomena atau kenyataan sosial yang berkenaan dengan problematika zakat profesi di Desa Dharma Tanjung Kecamatan Camplong Kabupaten Sampang.

\section{Kerangka Teoritik Zakat Profesi}

\section{Pengertian Zakat}

Kata zakat merupakan kata dasar (masdar) dari zaka yang berarti berkah, tumbuh, bersih dan baik. Sesuatu itu zaka berarti tumbuh dan berkembang, dan seseorang itu zaka, berarti orang itu baik. Dari segi istilah fiqih berarti sejumlah harta tertentu yang diserahkan Allah kepada orang-orang yang berhak, di samping berarti mengeluarkan jumlah tertentu itu sendiri. 8

Zakat menurut bahasa adalah tumbuh dan bertambah, dan menurut syari'at adalah kewajiban pada harta tertentu untuk diberikan pada kelompok tertentu dalam waktu tertentu. Sedangkan menurut istilah berarti sejumlah harta tertentu yang diwajibkan oleh Allah swt.

Zakat merupakan salah satu dari rukun besar Islam yang konsep pendistribusiannya telah jelas dituliskan dalam surat AlQur'an. Untuk menciptakan keadilan sosial ekonomi dalam bermasyarakat, instrumen zakat merupakan salah satu jawaban yang dapat mewujudkan semua itu, zakat dapat menjadi penunjang pembangunan masyarakat. ${ }^{9}$

2. Syarat-syarat Harta Yang Wajib dizakati

Menurut para ahli hukum Islam, ada beberapa syarat yang harus dipenuhi kewajiban zakat dapat dibebankan pada harta yang

\footnotetext{
${ }^{8}$ Yusuf Qaradhawi, Hukum Zakat (Jakarta: Muassat Ar-Risalah, 1973),. 44.

${ }^{9}$ Abdul Azis, Manajemen Investasi Syari'ah (Bandung:Alfabeta, 2010),. 210-211.
} 
Ananda

Azhar Amrullah Hafizh

Rusdiana Navlia

dipenuhi oleh orang muslimin. ${ }^{10}$ tidak semua kekayaan harus dikeluarkan zakatnya, sebab karena kekayaan yang dikeluarkan zakatnya harus jelas siapa pemiliknya, bagaiman status pemiliknya, apa jenisnya, berapa kadarnya, bagaimana sifat kekayaan itu (tetap atau dalam keadaan berkembang). Kriteria persyaratannya adalah:

a. Milik orang Islam, merdeka ${ }^{11}$

b. Sudah menjadi milik sepenuhnya

c. Berkembang 12

d. Harta zakat harus lebih dari kebutuhan pokok

e. Harta zakat harus bebas dari sisa utang13

f. Cukup nishab

g. Dimiliki setahun

3. Yang Berhak Menerima Zakat

Adapun kelompok yang berhak menerima zakat atau yang lazim disebut mustahik (orang yang berhak):

a. Fakir.

b. Miskin. ${ }^{14}$

c. Muallaf adalah mereka yang baru masuk Islam.

d. Riqab adalah kelompok yang memerdekakan budak

e. Amil adalah mereka yang diangkat oleh pihak yang berwenang yang diberikan tugas untuk melaksanakan berbagai kegiatan yang berkaitan dengan zakat. 15

f. Ghorimin adalah orang yang terlilit hutang

g. Ibnu sabil adalah orang yang dalam perjalanan

h. Fisabilillah adalah orang yang berjuang dijalan Allah ${ }^{16}$

\section{Zakat Profesi}

${ }^{10} \mathrm{Ibid}, .41$.

${ }^{11}$ Sudirman, Zakat Dalam Pusaran Arus Modernitas (Malang: UIN Malang Press, 2007), 25.

12 Ibid, 31.

13 Mohammad Daud Ali, Sistem Ekonomi Islam Zakat Dan Wakaf (Jakarta: Universitas Indonesia, 1988),. 223.

14 Syarif Hidayatullah, Ensikilopedia Rukun Islam Ibadah Tanpa Khilafiah Zakat (Jakarta: Indocamp,2008), 10.

${ }^{15}$ Nurul Huda, Lembaga Keuangan Islam: Tinjauan Teoritis Dan Praktis (Jakarta:Prenada Media Group, 2010),. 301-302.

16 Osmad Muthaher, Akuntansi Perbankan Syari'ah (Yogyakarta: Graha Ilmu, 2012),. 182. 
Zakat profesi adalah buah dari hasil kerja menguras otak dan keringat yang dilakukan oleh setiap orang, sesuai dengan profesi yang dikerjakan baik itu pekerjaan yang mengandalkan kemampuan otak maupun kemampuan fisik lainnya dan bahkan kedua-duanya. ${ }^{17}$

\section{Hasil Penelitian}

Setelah peneliti melakukan penelitian terhadap masyarakat nelayan tentang zakat profesi di Desa Dharma Tanjung Kecamatan Camplong Kabupaten Sampang, dengan mengumpulkan data dan kemudian memaparkannya sesuai dengan yang diperoleh di lapangan, maka peneliti menemukan beberapa hal sebagai bentuk temuan penelitian sebagaimana berikut ini :

Bahwa pandangan masyarakat nelayan di Desa Dharma Tanjung Kecamatan Camplong Kabupaten Sampang terhadap kewajiban zakat adalah bahwa mereka hanya mengetahui kewajiban zakat fitrah saja. Mereka tidak memahami takaran dan nisab yang harus dibayarkan setelah mendapatkan hasil tangkapan ikan yang banyak. Mereka juga menganggap bahwa pembagian kepada mustahiq dicukupkan kepada para buruh nelayan mereka sendiri, selain dibagikan ke masjid dan musholla. Secara umum para muzakki tidak mengeluarkan zakat sebagaimana yang telah ditetapkan dalam agama Islam melainkan hanya membagikan amal setiap bulannya karena itu sudah menjadi tradisi turun temurun masyarakat nelayan yang ada di Desa Dharma Tanjung Kecamatan Camplong Kabupaten Sampang.

Pandangan masyarakat nelayan yang ada di Desa Dharma Tanjung Kecamatan Camplong Kabupaten Sampang mengenai hasil laut ini memang tidak ada landasan yang kuat, apalagi jika dilihat dari perspektif surah Al-Baqarah ayat 267, yang menjelaskan bahwa setiap usaha yang menghasilkan uang dan memenuhi syarat, baik nisab maupun haul, maka wajib dikeluarkan zakatnya. Adapun waktu untuk mengeluarkan zakat hasil laut sama dengan zakat tanaman yaitu disaat hasil itu diperoleh.

Pandangan masyarakat nelayan yang ada di Desa Dharma Tanjung Kecamatan Camplong Kabupaten Sampang di atas memunculkan implikasi hukum yaitu:

\footnotetext{
17 Arief Ufraini, Akuntansi Manajemen Zakat (Jakarta: Kencana Prenada Media Group,
} 2012), 78. 
Ananda

Azhar Amrullah Hafizh

Rusdiana Navlia

Pertama, Kadar zakat yang tidak sesuai dengan tuntunan hukum Islam. Masyarakat nelayan di desa Dharma Tanjung mengeluarkan harta dari penghasilan yang mereka dapatnya, akan tetapi mereka tidak mengerti status dari harta yang mereka keluarkan tersebut, sehingga tidak ada kejelasan tentang takaran yang harus mereka keluarkan dari harta mereka keluarkan tersebut. Padahal dalam hukum Islam Syarat kewajiban zakat hasil laut adalah sampainya nisab dan muzakkinya adalah orang yang wajib mengeluarkan zakat. Kadar zakat yang seharusnya dikeluarkan adalah 2,5\% dari jumlah harta yang mencapai nisabnya. Adapun waktu yang wajib untuk mengeluarkan zakat hasil laut yaitu langsung setelah mendapatkan tangkapan hasil laut dan dijual, lalu membagikan kadar zakatnya kepada orang yang berhak tanpa harus menunggu selama satu tahun (1 haul).

Kedua, Masyarakat hanya mengetahui zakat fitrah, Sehingga zakat fitrah adalah zakat yang paling utama yang harus mereka keluarkan setiap tahunnya, sedangkan untuk zakat profesi mereka tidak begitu memahaminya. Meskipun sebenarnya mereka sudah mengeluarkan harta, hanya saja harta tersebut tidak diketahui statusnya apakah sebagai zakat atau infaq karena dikeluarkan setiap bulan tanpa ada penghitungan kadar zakat secara hukum Islam.

Jika melihat sejarah, kewajiban zakat dimulai secara tegas dan jelas pada tahun ke-2 hijrah. Kewajiban zakat fitrah dimulai sejak periode Mekkah, sekalipun kewajibannya belum tegas dan syariatnya belum jelas. Bagi orang-orang kaya yang mengetahui kewajiban zakat namun tetap mengingkarinya, maka ia dihukumkan kafir dan diperlakukan sebagai orang-orang murtad yang harus disadarkan atau dibunuh. Mengingkari kewajiban zakat, menurut kesepakatan ulama fiqih hukumnya kafir, dalam hal ini Imam An-Nawawi (tokoh fiqih syafi'iyah) mengatakan bahwa bila orang yang mengingkari kewajiban zakat itu adalah orang yang belum mengetahui dan disebabkan baru masuk Islam, atau tinggal di daerah pedalaman dan tidak ada yang memberitahukannya, maka dia tidak dihukumi kafir. Kewajiban ulama untuk memberitahukannya dan mengambil zakatnya, jika ia tidak mau maka ia dianggap telah kafir.

Ketiga, Pembagian zakat yang salah sasaran, karena menurut pandangan masyarakat: Musholla, Masjid, anak yatim, janda, saudara dan juga keponakan berhak menerima pembagian zakat, karena mereka adalah tetangga dekat dan dapat diminta bantuan bila suatu 
saat diperlukan tanpa melihat apakah orang-orang tersebut berhak menerima zakat secara hukum Islam ataukah tidak. Dalam hukum Islam, seorang muslim yang memiliki kelebihan harta diperintahkan untuk mengeluarkan atau membagi zakat kepada orang yang berhak yaitu para mustahiq zakat. Zakat tidak asal dikeluarkan atau dibagikan kepada seseorang, melainkan harus tepat pada sasaran, yaitu kepada: fakir, miskin, muallaf, riqab, amil, ghorimin, ibnu sabil dan fisabilillah.

\section{Penutup}

Berdasarkan deskripsi temuan dan pembahasan hasil penelitian sebagaimana telah dibahas di atas, maka dapat disimpulkan bahwa pandangan masyarakat nelayan di Desa Dharma Tanjung Kecamatan Camplong Kabupaten Sampang adalah menganggap bahwa kewajiban zakat hanya ketika mengeluarkan zakat fitrah saja dan menganggap harta yang mereka keluarkan setiap bulannya adalah representasi dari zakat profesi. Pandangan tersebut memunculkan implikasi hukum yaitu bahwa terjadi pemberian kadar zakat yang tidak sesuai dengan tuntunan hukum Islam, adanya keterbatasan pengetahuan tentang kewajiban zakat, dan pembagian zakat yang tidak tepat sasaran.

\section{Daftar Pustaka}

Abidin, Zainal. Figh Kontemporer. Pamekasan: STAIN Pamekasan Press, 2010.

Ali, Mohammad Daud. Sistem Ekonomi Islam Zakat Dan Wakaf. Jakarta: Universitas Indonesia, 1988.

Azis, Abdul. Manajemen Investasi Syari'ah. Bandung:Alfabeta, 2010.

Daradjat, Zakiyah. zakat pembersih harta dan jiwa. Bandung: PT Remaja, 1991.

Hidayatullah, Syarif. Enkilopedia Rukun Islam Ibadah Tanpa Khilafiah Zakat. Jakarta: Indocamp, 2008.

Huda, Nurul. Lembaga Keuangan Islam: Tinjauan Teoritis Dan Praktis. Jakarta:Prenada Media Group, 2010. 
Ananda

Azhar Amrullah Hafizh

Rusdiana Navlia

Indonesia, Departemen Agama Republik. Al-Qur'an dan Terjemahan. Jakarta:Yayasan Penyelengara Penterjemahan Al-Qur'an, 1971.

Inoed, Amiruddin. Anatomi Figh Zakat. Palembang: Pustaka Pelajar, 2005.

Moleong, Lexy J. Metode Penelitian Kualitatif. Bandung: PT Remaja Rosdakarya, 2014.

Muthaher, Osmad. Akuntansi Perbankan Syari'ah. Yogyakarta: Graha Ilmu, 2012.

Prastowo, Andi. Metode Penelitian Kualitatif. Jogjakarta: Ar-Ruzz Media, 2012.

Qaradhawi, Yusuf. Hukum Zakat. Jakarta: Muassat Ar-Risalah, 1973.

Sudirman. Zakat Dalam Pusaran Arus Modernitas. Malang: UIN Malang Press, 2007.

Ufraini, Arief. Akuntansi Manajemen Zakat. Jakarta: Kencana Prenada Media Group, 2012. 